\title{
Study of Anthelmintic Activity of Aegle Marmelos Fruit Extract on Indian Earthworm Model
}

\author{
Piyush Wagh, Laxman Deshmukh and Pratima Thakur* \\ Department of Pharmacology, Smt. Kashibai Navale College of Pharmacy, India
}

Submission: February 15, 2017; Published: March 09, 2017

*Corresponding author: Pratima Thakur, Department of Pharmacology, Sinhagad Technical Education Society's Smt. Kashibai Navale College of Pharmacy, Kondhwa (BK), Pune - 48, India, Tel: +1 443356 2411; Email: pratimathakur@hotmail.com

\section{Abstract}

Objective: Soil transmitted helminthiases and anthelmintic resistance pose major concern to the human and animal health. Therefore, there is a dire need to identify new sources of anthelmintic drug molecules. One such source could be herbal drugs commonly used in India for the treatment of helminthiases.

Methods: All solutions were freshly prepared before experiment. Earthworms were washed with distilled water and placed in various concentration of the aqueous extract of ripe shed dried fruits of Aegle marmelos (1, 2, 10, $20 \mathrm{mg} / \mathrm{ml})$. Distilled water control was used to compare the results.

Results: The selected doses of aqueous extract of ripe shed dried fruits of Aegle marmelos at the concentration of $1 \mathrm{mg} / \mathrm{ml}$ dose showed significant difference in paralysis and death time when compared with the vehicle control group $(\mathrm{P}<0.001)$. Dose dependant activity was observed with the increasing doses.

Conclusion: The aqueous extract of ripe fruits of Aegle marmelos may possess anthelmintic potential.

Keywords: Anthelmintic; Earthworm; Aegle marmelos

\section{Introduction}

Helminthiasis is one of the major causes of morbidity in the world, especially in the developing countries. Approximately 300 million people suffer from severe helminthiases morbidity on this earth resulting into 10,000-135,000 deaths per year [1]. Infection occurs from ingested eggs from food and water and by penetration of skin with soil containing larvae. The Soil Transmitted Helminthiases (STH) consists of hookworm, pinworm and whipworm. These parasites reside in gastrointestinal tract, but they may also burrow in the other parts of the body such as liver and heart. The STH causes high percentage of morbidity like anemia, low birth weight, malnutrition, loss of appetite [2,3]. In addition helminth infection impairs immune response of the host making them vulnerable to the life threatening infections such as HIV and tuberculosis. The Aegle marmelos (Family - Rutaceae), usually known as Bilwa, a deciduous and evergreen tree is an indigenous species from Asia. Ripe fruitsof this tree are used for curing diarrhea, gastric trouble and as heart tonic in India $[4,5]$. However, there are not much biological studies on Aegle marmelos for the anthelmintic activity specifically although it has been mentioned for the treatment of various stomach ailments. Therefore, we decided to perform a systematic study of dried ripe fruits of this plant for anthelmintic activity. In the first step toward this study we decided to use aqueous extract from the ripe fruits of this tree and Indian earthworm model to study wormicide effect in our experiments.

\section{Materials and Methods}

\section{Plants material}

The ripe and shed dried fruits of Aegle marmelos were procured from Nashik region and authenticated by the Department of Botany, Agharkar Research Institute, Pune, India. $200 \mathrm{gm}$ fruit was extracted with $400 \mathrm{ml}$ of distilled water for $12 \mathrm{~h}$ and dried residue was collected by vacuum evaporation method [6]. The doses of freshly prepared aqueous extract were selected randomly as $1,2,10$, and $20 \mathrm{mg} / \mathrm{ml}$. 


\section{Indian adult earthworm- experimental model}

Due to the anatomical and physiological resemblance with the intestinal round worm parasite of humans Pheretima prostuma earthworms $(6-10 \mathrm{~cm}$ long and 1-2 $\mathrm{cm}$ wide) were used as animal model for the screening $[7,8]$.

\section{Screening of anthelmintic activity}

The earthworms were divided into five groups containing 20 earthworms in each group. The earthworms were kept in glass petridishes for the respective treatments as vehicle control (distilled water) and aqueous extract of 1,2, 10 and $20 \mathrm{mg} / \mathrm{ml}$ each. Observations were made for the time taken for paralysis/ immobility. Paralysis/immobility was confirmed by placing the earthworm in hot water at $60 \mathrm{oC}$. Death time was recorded when the worms lost their mobility followed with their body color fading away. All the results were expressed as mean \pm SEM of 20 earthworms in each group.

\section{Results}

Table 1: Summarized results of effects of various concentrations of aqueous extract of dried ripe fruits of Aegle marmelos on paralysis and death time using Indian earthworm model.

\begin{tabular}{|c|c|c|c|c|}
\hline Treatment & Concentration $\mathbf{( m g} / \mathbf{m l})$ & Paralysis time (min) & Death time (min) & P value \\
\hline $\begin{array}{c}\text { control group } \\
\text { (distilled water) }\end{array}$ & no paralysis was seen & $4320 \pm 0.00$ & $\cdots$ \\
\hline \multirow{3}{*}{$\begin{array}{c}\text { Aqueous extract Aegle } \\
\text { marmelos }\end{array}$} & 1 & $115.3 \pm 5.02$ & $167.2 \pm 8.31$ & $*-$ \\
\cline { 2 - 5 } & 2 & $80.23 \pm 6.3$ & $121.2 \pm 4.08$ & $* * *$ \\
\cline { 2 - 5 } & 10 & $55.25 \pm 3.03$ & $74.58 \pm 3.39$ & $* * *$ \\
$* * *$ & $48.08 \pm 1.48$ & \\
\hline
\end{tabular}

The aqueous extract of the ripe and shed dried fruits of Aegle marmelos with1, 2, 10 and $20 \mathrm{mg} / \mathrm{ml}$ concentrations showed dose dependent wormicide activity when compared with the distilled water control group. Paralysis was caused by the loss of external stimuli which eventually progressed to death. The group treated with $20 \mathrm{mg} / \mathrm{ml}$ dose showed $34.42 \pm 2.16 \mathrm{~min}$ time required for the paralysis and the average death time in this group was observed as $48.08 \pm 1.48 \mathrm{~min}$ as compared to the death time recorded in distilled water control group of 4320 $\pm 0.00 \mathrm{~min}$. There was no paralysis recorded in the distilled water control group. The most potent anthelmintic activity was observed at the dose of $20 \mathrm{mg} / \mathrm{ml}$. However, both paralysis and death were observed at the lowest concentration of $1 \mathrm{mg} / \mathrm{ml}$ used in this study as shown in the Table 1. Analysis of the data was performed using GraphPad Prism 5 version 5.01. One way ANOVA test with confidence interval at $95 \%(*=p \leq 0.05)$ was used to determine the statistical significance of the differences of the means.

\section{Discussion}

Due to the heavy use of broad spectrum anthelmintic drug albendazole anthelmintic resistance is a major challenge today, which is already being noticed in live stocks. Therefore, development of new anthelmintic drug molecules that are effective against broad spectrum for human nematode as well as inexpensive to achieve World Health Organization (WHO) goals for global control of morbidity caused by STH infection is mandatory [3]. From the above results, dose dependent activity of the aqueous extract of the ripe fruits of Aegle marmelos was observed. In the given study the drug was effective at a very low concentration of $1 \mathrm{mg} / \mathrm{ml}$. Therefore it can be concluded that the aqueous extract of dried ripe fruit extract of Aegle marmelos has a potent wormicide activity when compared with the vehicle control group. Therefore, in view of the new drug development for the treatment of helminthesis further studies shall prove highly beneficial to establish the effectiveness of the use of Aegle marmelos as a novel putative anthelmintic drug.

\section{Acknowledgment}

We are thankful to Smt. Kashibai Navale College of Pharmacy, Pune, India for providing the facilities required for this study.

\section{References}

1. Brooker S, Hotez PJ, Bundy DA (2008) Hookworm-related anaemia among pregnant women: a systematic review. PLoS Negl Trop Dis 2(9): e291.

2. Stephenson LS, Latham MC, Ottesen EA (2000) Malnutrition and parasitic helminth infections. Parasitology 121: S23-S38.

3. Geary TG, Chibale K, Abegaz B, Andrae-Marobela K, Ubalijoro E (2012) A new approach for anthelmintic discovery for humans. Trends Parasitol 28(5): 176-181.

4. Sandeep Dhankhar, S Ruhil, M Balhara, Seema Dhankhar, AK Chhillar (2011) Aegle marmelos (Linn.) Correa: A potential source of Phytomedicine. Journal of Medicinal Plants Research 5(9): 1497-1507.

5. Rana BK, Singh UP, Taneja V (1997) Antifungal activity and kinetics of inhibition by essential oil isolated from leaves of Aegle marmelos. J Ethnopharmacol 57(1): 29-34.

6. Raja SB, Murali MR, Devaraj SN (2008) Differential expression of ompC and ompF in multidrug-resistant Shigella dysenteriae and Shigella flexneri by aqueous extract of Aegle marmelos, altering its susceptibility toward beta-lactam antibiotics. Diagn Microbiol Infect Dis 61(3): 321328.

7. Vidyarthi RD (1967) A Text Book of Zoology. S. Ch. and Co, India.

8. Vigar Z (1984) Atlas of Medical Parasitology. P.G. Publishing House, Singapore, pp. 242. 
This work is licensed under Creative Commons Attribution 4.0 License

DOI:10.19080/JPCR.2017.02.555586
Your next submission with Juniper Publishers will reach you the below assets

- Quality Editorial service

- Swift Peer Review

- Reprints availability

- E-prints Service

- Manuscript Podcast for convenient understanding

- Global attainment for your research

- Manuscript accessibility in different formats ( Pdf, E-pub, Full Text, Audio)

- Unceasing customer service

Track the below URL for one-step submission https://juniperpublishers.com/online-submission.php 